\title{
Death by chumbinho: aldicarb intoxication-regarding a corpse in decomposition
}

\author{
Carlos Durão $^{1,2} \cdot$ Marcos P. Machado $^{3}$
}

Received: 12 December 2015 / Accepted: 10 February 2016

(C) Springer-Verlag Berlin Heidelberg 2016

\begin{abstract}
Chumbinho is the popular name given to carbamate aldicarb (Temik), an insecticide commonly used in agriculture and highly toxic (LD50 $=0.9 \mathrm{mg} / \mathrm{kg}$ oral in rats) that has been sold clandestinely in several regions of Brazil. Chumbinho is sold illegally as raticide and is available in a formulation of small black granules which are easily mixed with food for criminal purposes, its use often being attributed to accidents and suicides, hence the importance of its inclusion in the toxicology studies of suspicious deaths. With the corpse putrefaction, many pathological and toxicological anatomical parameters are damaged or lost. This study emphasizes the importance of the gastric content observation, which in this case has, despite the advanced putrefaction, recognized the presence of chumbinho and guide its toxicological confirmation.
\end{abstract}

Keywords Chumbinho $\cdot$ Aldicarb $\cdot$ Carbamate $\cdot$ Pesticides · Fatal intoxication

Carlos Durão

drcarlosdurao@hotmail.com

1 National Institute of Legal Medicine and Forensic Sciences, Lisbon, Portugal

2 Trauma and Orthopaedics Department, Hospital Vila Franca de Xira, Estrada Nacional n 1 , Povos, 2600-009 Vila Franca de Xira, Lisbon, Portugal

3 Department of Forensic Anthropology, Legal Medicine Institute Afrânio Peixoto, Rio de Janeiro, Brazil

\section{Introduction}

Chumbinho is the popular name of carbamate aldicarb, a highly toxic insecticide (LD50 $=0.9 \mathrm{mg} / \mathrm{kg}$ oral in rats) that has been sold clandestinely in several regions of Brasill [1-4].

Aldicarb (propanal, 2-methyl-2-(Methylthio)-O-[(methylamino) carbonyl] oxime) (Figs. 1, 2, and 3) is a carbamate used in agriculture as an insecticide and nematicide [5], sold in Brazil in the form of a granulated pesticide Temik-150 by Bayer CropSciences AG, and possesses exclusive license for agricultural use in the cultivation of cotton, potatoes, coffee, sugarcane, citrus, and beans [1].

Aldicarb has a characteristic dark gray color, but has no taste or characteristic smell, being difficult to be detected. In cases of attempt intoxications, aldicarb is usually mixed with dark color foods such as chocolate or beans.

Aldicarb is easily absorbed by the gastrointestinal tract, skin, and quickly spread into the bloodstream after inhalation. Its metabolites (aldicarb sulfoxide and aldicarb sulfone) also have severe toxicity, the reason why it should be handled using masks and gloves [1].

Carbamates are potent cholinesterase inhibitors as well as organophosphates, although short-lived and of reversible action unlike organophosphates, promoting the increase of

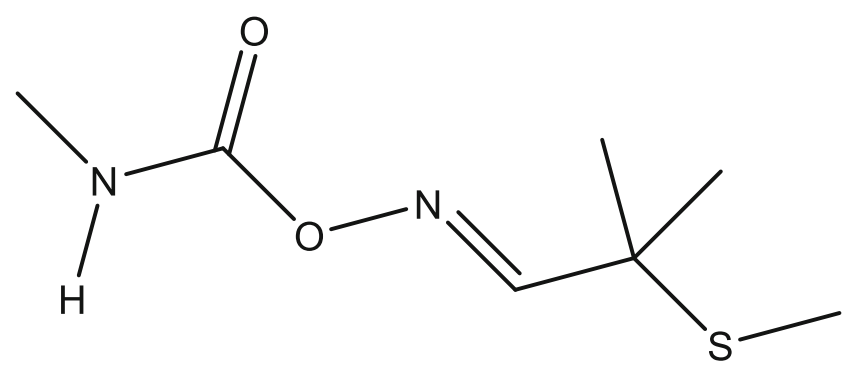

Fig. 1 Aldicarb chemical structure 
Fig. 2 a external aspect of cadaverous decomposition. $\mathbf{b}$ Details of the presence of numerous granules (chumbinho) adhered to the gastric mucosa
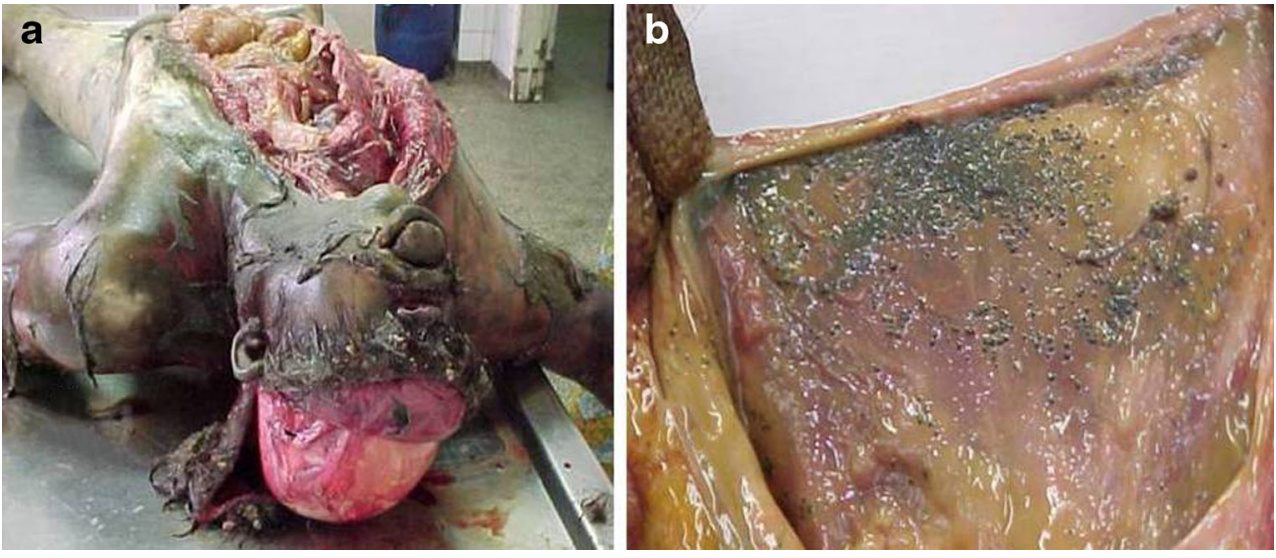

cholinergic stimulation by acetylcholine accumulation (neurotransmitter) in the synaptic cleft [6, 7].

Usually, in cases of suspected poisoning, routine life support measures - airway establishment, breathing, and cardiac support (ABC) - must be evaluated, and if action is needed it must be started promptly. When the suspicion of carbamate use is confirmed, additional specific treatments are evaluated: the induction of emesis, use of active charcoal, and the antidote atropine $[7,8]$. Atropine is a competitive inverse agonist for the muscarinic acetylcholine receptor and its use has been spread as an antidote for organophosphate poisoning. Atropine blocks muscarinic acetylcholine receptors, which would otherwise be overstimulated, by excessive acetylcholine accumulation.

The most observed clinical changes are neurological and cholinergic signs such as sweating, salivation, miosis, bronchial hyper secretion, respiratory failure, bronchospasm, cough, vomiting, mental confusion, and seizures [6].

Although several fatal poisonings are known since the 1980s, with an unaccounted and growing number of medical consultations in all of Brazil's emergency services [9, 10], descriptions of autopsies by Aldicarb intoxication are particularly rare in forensic literature [5], which justifies the importance of the documentation of these cases.
Obtaining this pesticide in the Brazilian informal trade and the popular culture of its effects can allow for it to be easily purchased, transported, and used as poison in countries where its use is much more controlled [11].

\section{Case report}

A 46-year-old man was found in his residence in supine position in advanced stage of putrefaction and circumstantially identified. The internal examination of the body was hampered by organic decomposition but the autopsy allowed to dismiss signs of traumatic injuries. During the opening of the stomach, many black granules suggestive with the chumbinho intake were identified, which were collected along with blood samples for toxicological study. Confirmation of aldicarb was determined by gas chromatography-mass spectrometry methodology previous described by Papoutsis I., et al. (2012) [12] with some modifications. The concentration found was $7.8 \mu \mathrm{g} / \mathrm{mL}$ in blood and $62.3 \mu \mathrm{g} / \mathrm{g}$ in the stomach content. The toxicological result was crucial for the total identification of the case.
Fig. 3 a Chumbinho granules . b Flagrant the illegal sale of chumbinho in the informal market
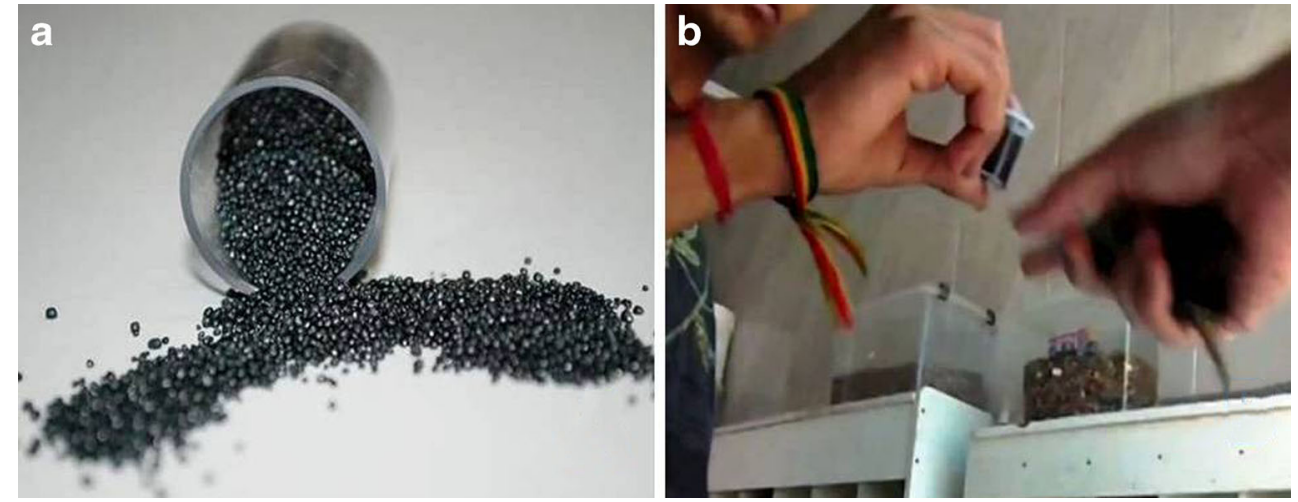


\section{Discussion}

The deviation of this pesticide and its illegal sale is a public health problem. Indiscriminate use as a raticide contaminates the soil and food and facilitates the accidental ingestion by children and domestic animals.

The voluntary intake of chumbinho is observed in suicide [13], where it is usually possible, such as in this case, to observe a lot of dark granules, dispersed or concentrated in porridge. The combination with alcohol is another given factor in favor of suicide. Lack of food content suggests a more voluntary intake.

Regarding murder, by poisoning, the most common is its concealment in foods such as black beans (typical Brazilian dish) or brigadeiros (chocolate candies) that for being dark allow greater dispersion of the chumbinho. There is almost always some intimate relationship between the victim and the aggressor, as in crimes of passion. In the case of poisoning food and animal feed, the concern is to disguise the taste, whether the intention is to kill domestic animals like cats and dogs in order to facilitate the execution of other crimes such as assaults, or even mere revenge, as also described in other countries [14].

Because it is an illegal and clandestine trade, and consequently does not undergo supervision and quality control, it is customary to find adulterated chumbinho, mixed with graphite, ground corn, sand, or anticoagulants, which influences directly the toxicity of each product [9].

\section{Conclusion}

Knowledge of clinical signs and death circumstances is very important in the observation of poisoning and in the interpretation of forensic etiology. Currently, pesticides are given the addition of emetics and have a strong odor in order to prevent accidental ingestions allowing often observation of vomiting near the victim.

Even in a corpse with an advanced state of putrefaction, it may be possible to identify the cause of death. The recognition of chumbinho inside the stomach was crucial to its research and confirmation in the toxicology test as the cause of death from acute poisoning. The examination of the gastric mucosa in oral poisonings can reveal bleeding, swelling, and color changes as well as histological findings that can assist the medical legal study [15].

The necroscopic findings and the circumstantial story in this case strongly suggested a suicide, although one cannot strictly differentiate the forensic etiology between a suicide and a possible homicide.

\section{References}

1. Brazilian Sanitary Surveillance Agency (Agência Nacional de Vigilância Sanitária, ANVISA), Monografias de Produtos Agrotóxicos, http://www.anvisa.gov.br/ toxicologia/monografias/ index.htm, retrieved March 12, 2010

2. Caldas LQA, Unes AF (1998) Forbidden rodenticide leading to increasing death rates in Brazil. Toxicol Lett 95(1):142

3. Caldas ED, Rebelo FM, Heliodoro VO, Magalhães AFA, Rebelo RM (2008) Poisonings with pesticides in the Federal District of Brazil. Clin Toxicol 46:1058-1063

4. Bucaretchi $\mathrm{F}$ et al (2012) Poisoning by illegal rodenticides containing acetylcholinesterase inhibitors (chumbinho): a prospective case series. Clin Toxicol 50(1):44-51. doi:10.3109/ 15563650.2011 .639715

5. Proença $\mathrm{P}$ et al (2004) Aldicarb poisoning: one case report. Forensic Sci Int 146S:S79-S81

6. King AM, Aaron CK (2015) Organophosphate and carbamate poisoning. Emerg Med Clin North Am 33(1):133-151

7. Dreishach RH, Robertson WO (1982) Handbook of Poisoning. Appleton and Large Publications, Los Atlos

8. Anastasio JD, Sharp CR (2011) Acute aldicarb toxicity in dogs: 15 cases (2001-2009). J Of Vet Emerg Crit Care 21(3):253-260

9. Lima JS, Reis CAG (1995) Poisoning due to illegal use of carbamates as a rodenticide in Rio de Janeiro. Clin Toxicol 33:687-690

10. Vieira JLF, Silva BA, Silva EEG (2006) Chemical identification of granulated rodenticides market in Belém-Pará. Rev Paraense Med 20:19-21

11. http://g1.globo.com/sao-paulo/sorocaba-jundiai/noticia/2015/01/ de-venda-ilegal-chumbinho-pode-ser-facilmente-comprado-emsorocaba.html

12. Papoutsis I et al (2012) Development and validation of a simple GC-MS method for simultaneous determination of 11 anticholinesterase pesticides in blood - clinical and forensic toxicological applications. J For Sci 57(3):806-812

13. Van Brussel E, Ghuysen A (2014) Acute voluntary poisoning by carbamate. Rev Med Liege 69(12):650-653

14. Tennakoon S, Perera B, Haturusinghe L Intentional poisoning cases of animals with anticholinesterase pesticide-carbofuran in Sri Lanka. Legal Med 11, S500-S502

15. Sperhake J, Tsokos M, Sperhake K (1999) Perimortem fixation of the gastric and duodenal mucosa: a diagnostic indication for oral poisoning. Int J Legal Med 112:317-320 